\title{
Bactericidal Properties of Biogenic Silver Nanoparticles Synthesized from Dematiaceous Airborne Fungi ${ }^{\dagger}$
}

\author{
Bijaya Kumar Nayak ${ }^{1}$, Chitra N. ${ }^{2}$, Anima Nanda ${ }^{2, *}$ \\ 1 Department of Botany, Kanchi Mamunivar Govt. Institute for Postgraduate Studies and Research (Autonomous), \\ Puducherry-605008 \\ 2 Department of Biomedical Engineering, Sathyabama Institute of Science and Technology, Deemed to be University, \\ Chennai- 600119 \\ * Correspondence: animananda72@gmail.com; \\ $\dagger$ Presented at International e-Conference on Bioengineering for Health and Environment (ICBHE 2020)
}

Received: 5.07.2020; Revised: 10.07.2020; Accepted: 12.07.2020; Published: 15.07.2020

\begin{abstract}
Analysis of the extracellular biosynthesis of AgNPs was made from dematiaceous airborne microfungi and were processed for their antibiotic potential against pathogenic clinical bacterial strains procured from Imtech, Chandigarh, India. Characterization done by UV-VIS spectroscopy, FESEM, FTIR, and XRD confirmed the silver nanomaterials synthesized from the fungi. The antibacterial potency of the AgNPs was found to be very good against five bacterial pathogens viz., Bacillus cereus, Escherichia coli, Proteus vulgaris Staphylococcus aureus, and Vibrio cholerae. The synergistic effect of silver nanoparticles synthesized from Alternaria solani with Tetracycline was found to be the maximum effective combined drug to control the pathogenic bacteria in comparison to the silver nanoparticles alone. MTT assay proved the AgNPs have no toxicity towards the Vero cell line at low concentration, and the nature of susceptibility of cells exposed to various AgNPs depends on the type and source of mammalian cells in vitro.
\end{abstract}

Keywords: Bactericidal properties; Biogenic silver nanoparticles; Dematiaceous airborne fungi; MTT assay; In Vitro.

(C) 2020 by the authors. This article is an open-access article distributed under the terms and conditions of the Creative Commons Attribution (CC BY) license (https://creativecommons.org/licenses/by/4.0/).

\section{Funding}

This research received no external funding.

\section{Acknowledgments}

This research has no acknowledgment.

\section{Conflicts of Interest}

The authors declare no conflict of interest. 